\title{
THE INFLUENCE OF TEACHING STYLE AND MOTOR SKILLS ON THE BOTTOM PASSING LEARNING OUTCOMES IN THE VOLLEYBALL
}

\author{
Ahmad Muchlisin Natas Pasaribu* \\ Muhammadyah University of Tangerang* \\ ahmadmuchlisinnatas@gmail.com*
}

\begin{abstract}
:
The purpose of this research is to find the effectiveness of teaching style to the learning outcomes of passing motor skills under the volleyball. The Method is Used by experiment with $2 \times 3$ factorial design. This research is Implemented at SMPN 3 Satu Atap Labura with sample of class VIII. The Results of This study concluded that: (1) There are no differences between the forces Teaching reciprocity and training on the learning outcomes of passing down in a manner Overall (2) there are differences between reciprocal teaching style and inclusion To the overall passing learning outcome (3) There are differences Between teaching practice style and inclusion to lower passing learning outcomes Overall. (4) There are interaction between teaching styles (reciprocal, training, And inclusion) and motor skills (high and low) on learning outcomes Passing down as a whole. (5) There are differences teaching styles Reciprocal and training on lower passing learning outcomes in students High motor skills. (6) There are a differences in reciprocal teaching style and Inclusion of lower passing learning outcomes in students with motor skills High. (7) There are different styles of practice teaching and inclusion to results Learn passing down on high skill motor students. (8) There are Differences in reciprocal teaching styles and training on passing learning outcomes (9) There are a differences in teaching styles reciprocity and inclusion to lower passing learning outcomes in students Low motor skills. (10) There are different teaching styles and practice Inclusion of lower passing learning outcomes in students with motor skills low
\end{abstract}

Keywords: Teaching Styles, Motor Skills, The result of passing down learning

The role of teachers in the process of physical education such as determining and choosing are an effective in teaching style so that students can understand and know the learning materials is presented in accordance with the expected goals. The ability of teachers to choose and present learning materials is determined by their ability and experience in learning. Therefore, to conduct the process of physical education, selected by learning styles are appropriate and easy to apply to students, so that various activities of physical education movement can be mastered properly and correctly.

But the reality found in the field, in the junior high school (SMP) Negeri 3 Satu atap, the learning process of physical education has not been so good, for example, When passing learning down in volleyball, there are many mistakes students get mistake and make in the movements required in the bottom passing The. For example, in the initial attitude of down passing the visible errors are very prominent, when the ball comes the arms are not straight to welcome the ball, the legs are less open shoulder width, knees are not bent, the body are not stand up at the initial attitude, both of arms are tense, the head is not directed to the view The direction of the ball comes in, when the ball comes to the student's lack of adjusting his arm swing in the shoulder joint. In attentiveness, there is still a mistake that is, students can not maximally adjust the speed of the arrival of the ball with the movement of the hand 
arm when touching the ball, hit the ball on the proximal of the upper arm of the wrist and at the time the arm forming the angle is also still not maximal, so the ball Can not be directed as expected. Then at the final stance in the bottom passing, the student does not return to the starting position of the bottom passing, the elbow should really be in a straight line and the hand is in a fisted condition and the knee returns the bent position. As a result, less effective learning process so that students difficulty learning pemas, either in the form of abilities and skills are as a whole, physical, mental and intellectual.

The ability of the teacher to choose and present the material of learning method is determined by his ability and experience in the process of learning volleyball. therefore, then to do the learning process of volleyball is chosen approach of teaching style that is appropriate and easy to apply to the student, so that various basic motion and movement coordination can be mastered properly and correctly. So to teach the basic bottom passing technique in volleyball selected by the right teaching style and easy to apply to the students, so that the subjects of volleyball can be mastered well. This styles of teaching are a reciprocal teaching style on the grounds to grow the creativity, sense of responsibility and independence of students are so as to foster the students' skills in the process of learning volleyball. Then the style of exercise In the style of teaching exercises its application teacher introduces, explains and demonstrates the tasks of passing down motion as a whole to the students. Then the style of inclusion, the purpose of this style is to understand how to choose tasks or activities that can be displayed and provide a challenge to evaluate the work itself. In this case the determination of the level of ability is determined by the students themselves concerned.

Learning outcomes are also an important indicator to be used in viewing the success of students in mastery of the concepts that have been studied. This is in accordance with the learning pillars that exist in our educational curriculum, one of the pillars of learning is learning to build and find the identity, through active, creative, effective, and fun learning process.1 Students' learning outcomes can fulfill the sphere Cognitive, affective domains, and psychomotor domains there are the targets of the learning outcomes themselves. Then, Sanjaya also stated that "outcomes learning represent the ability of students in fulfilling a stage of learning experience achievement in one basic competence. Thus, outcomes learning are the results obtained by the learners after implementing the learning process in which the learning process of learners must meet the affective of sphere, the cognitive of domain and the psychomotor domain. Outcomes Learning is as one indicator of achievement of learning objectives in the classroom can not be separated from the factors that affect the learning outcomes themselves. Mulyono mentioned the factors that influence outcomes learning can be internal factors from within and external from outside. So in the process of teaching and learning must be maintained a balance between the intellectual development of the subject matter with psychological development, namely the development of students as a whole person. 
In line with opinion According Djamarah and Zain. "Which indicates that a learning process is considered successful is the ability to absorb the lesson material that is taught to achieve high achievement both individually and in groups.1 Looking at the learning outcomes as the output of a processing system of various inputs.

Various input systems of the system in the form of deeds or performance (performance). Differentiate the two types of learning outcomes, knowledge and skills. Learning outcomes are the most important part of learning. According to Slameto "the results of learning is something that is obtained from a business process after doing learning activities that can be measured by using tests to see student progress. 2 Romiszowski said learning results obtained by students after experiencing the learning process, both in the form of knowledge and skills. The knowledge in question relates to the information stored in the mind, whereas the skill is related to the actions and reactions that a person undertakes in achieving a goal.3 Then according to Arends Suyitno, suggests that 'there are three learning outcomes obtained by the learner being taught using a problem-based learning model, That is, inquiry of problem solving skills, learning of adult rule models, and self-study skills. Thus the learning process is a way to be taken by students or people learning to understand / comprehend something previously unknown to apply what they have learned. There is also argued that the results of learning According to Shabri, is achieved by the students are affected by two main factors namely factors of the environment and factors that come from students themselves. Factors that come from students such as learning ability (intelligence), motor skills, ask and attention, attitudes and study habits, perseverance, physical and psychological factors.5

A volleyball game is a team sport played by two squads of each field separated by the net, the game must pass the ball over the net in order to fall to touch the floor in the opposite area and by preventing the same ball (skipping) not touching the floor in its own field, Each team can play three times the reflection (touch) to return the ball (except for the block). The advantages of volleyball are also expressed by Papageorgiou who stated "Volleyball is a game that is suitable for both sexes and for players of all ages and abilities and can be adapted to allow players with a physical or mental disability to play at competitive level". Sport volleyball as part of the material education chain of the body in the word meaning is part of the material education of the body as a whole. In addition volleyball sports as an educational tool, which enters the physical education of sports and health in schools. Volleyball is a sport that has been popular in the community and favored by all walks of life in Indonesia, both children, teenagers and adults. 2 To be able to play a game of volleyball requires a volleyball court consisting of a ground, or a cement floor or floor Board, bounded by a rectangular line with a hand line dividing the field into two spaced 3 meters and the length and width of the field measuring $18 \times 9 \mathrm{~m}$.

In addition to the field is also in need of other equipment such as net made from black meshes with thick with 2.43 for son and 2.24 for daughter, net width $1 \mathrm{~m}$ net length $9.50-10 \mathrm{~m}$. With side bands 
20-25 on each side. There is an antenna on the right and left side made of a flexible rod along the $1.80 \mathrm{~m}$ and $10 \mathrm{~mm}$ diameter made of fiberglass or similar high-end antenna on the net is $80 \mathrm{~cm}$ and given a contrasting line along the $10 \mathrm{~cm} "$.

Blume Gunter "In a game of volleyball practice technique is a very important component in the game of volleyball. Without good technique, game tactics can not be developed variably. Because the technique is one way to do or implement something in achieving certain goals effectively and efficiently ".

One of the basic techniques in volleyball is passing. Dewanti explains: "Without the mastery of a good passing technique, a team will not be able to handle the game well, because passing is the first step that will determine a team's ability to survive and attack. The meaning of passing by Subroto and Yudiana states that "passing in a game of volleyball is a term to play the first ball after the ball is in game due to an opponent's attack, opponent service, or net game (cover spike and cover block) .5 Passing down is a technique of playing ball With the inner forearm side either by using one or two arms simultaneously. The whole movement process in the bottom passing can be described as follows: The Prefix Attitude performs the bottom passing. Beginning attitude, normal preparedness, legs shoulder-width apart, knees bent with one aft legs forward with both arms relaxed beside the body, arms straight, as the ball comes the arm to welcome the ball. Both legs are straight with swinging arms.

Punch the ball on the arm, when perkenaan ball position of both arms straight. The batting of the ball is located on the forearm to make it easier to direct the ball in the desired direction. This movement should proceed smoothly and continuously without intermittent, followed by the movement of the arm in the desired direction.

After successfully beaten players maintain the balance of the body to more easily set the position when the ball comes back. It should be noted that while maintaining the balance after receiving the ball both feet in a flexible state (pinched). To be able to perform the bottom passing well in addition to the above basic techniques must also meet some requirements. According to Nuril Ahmadi, Preparation Attitude: (1) Move toward the arrival of the ball and set the position of the body (2) Fingers of the hand (3) Legs in a relaxed position relaxed, wide-open shoulders (4) Knee-resistant knee technique in low position (5) ) The shape of the base with the arms (6) The elbow is locked (7) The arms are parallel to the thighs (8) The straight angle (9) The view toward the ball.1 In this study the independent variables for increasing the passing ability under studied are by giving two kinds of elements Physical on the game of volleyball.

Teaching includes what the teacher can do to help students do tasks, listen to thinking, talk, read solve problems, answer questions, investigate and so on what teachers advise and advise. Teaching is seen in two aspects: teaching traditionally is conveying knowledge to students or students in school, while teaching in the modern process of teaching is defined as effort3. Teaching is essentially a process of 
organizing, organizing the environment around the students, so it can grow and encourage students to do the process of providing guidance or assistance to students in learning process 4 .

Teaching style is the process of delivering information or knowledge from teachers to students5. Therefore a teacher should be able to create bridges or intermediaries connecting students with interaction and subject matter, as well as harmony of all parties in the activity, both teachers and students themselves. Implementation of teaching and learning activities should have interaction, ispiratif, fun, challenging, motivate participants, so that learners participate more actively and provide sufficient space for the initiative, in the creation and independence in accordance with the talents, interests and physical and psychological development of learners. There are two approaches in learning that are teacher ceneter approach and students centered approach (Student Centererd approaches1), thus goal is a very decisive factor for teaching and learning activities (Hasbullah, 2. Davis and friends. 3 Defining the style of teaching has something to do with the way in which a teacher chooses to deal with the scope of the decisions in the teaching process.Therefore, a teacher is required to create an intermediary that can connect the student with the subject matter, as well as the harmony of all parties in Such activities as teachers, subject matter and students. 4 So the main purpose of teaching is the mastery of the subject matter5.

The teaching spectrum shows the teacher's role shift to students in decision making. The decision set consists of: (1) before the meeting (pre impact), the decisions should be made during the first contact between the teacher and the student (2) during the meeting, the decisions must be made at the time of doing, (3) ) After the postimpact, the decisions taken at the evaluation stage of giving feedback to the students.6 Furthermore, no less important than the value of the learning process is the result of optimal learning or maximum.7 Teaching is a pattern of thinking and interacting Learned (including self-taught) in various fields of education8.

From the overall style of teaching above in this study selected three teaching styles used as research materials, namely the reciprocal teaching style, the style of teaching practice (practice style) and the inclusion style of teaching (the inclusion style),

The first teaching style is the reciprocal teaching style. Teaching style in groups (ReciprocalStyle) is Students are responsible for observing the appearance of friends or spouses and provide immediate feedback on every time do the movement9. According to Mosston in this style of teaching, some decisions regarding teaching activities shift from teacher to student. In line with the above statement according to Trachi and Pianto10 the results of research show that reciprocal teaching style is more able to create more interaction among learners, so based on the research shows that reciprocal teaching style more emphasize on ability of learners to communicate directly and able Provide feedback on the performance results of other learners. According Huda11 reciprocal learning or reciprocal learning is a 
learning strategy to improve understanding. Students in this case are given more responsibility, ie make some decisions regarding the execution of tasks and provide feedback to his friends. While the observer is giving feedback to the offender based on the criteria conveyed by his teacher. The feedback technique performed by the observer may be given during the complete execution by the actor after the movement is complete and complete, the member of the couple may change the role, ie the offender becomes the observer, while the observer becomes the perpetrator.

According to triyanto12 Students take turns to be teachers in their group, pass on understanding to their group mates, and teachers turn to facilitators, mediators, trainers and support and feedback for students. If each member has undergone a role, the implementation of the above task is considered complete. Based on the results of the research by Byra and Marks.13 The research results show that the observer gives specific feedback more often done by close friends than to strangers. According to Aris Shoimin 14 that the learning strategy of reciprocal teaching students acts as a "teacher" to convey material to his friends. This also reinforced the results of research by henning dkk15 stating that the reciprocal teaching style can improve motor skills, whereas according to Kolovelonis et.al16 in his research showed that reciprocal style is effective to improve learners' performance in physical education subject. The practice teaching style (practicestlye) is one of the most suitable teaching models applied to the lesson. So the teaching style of the exercise is the style that involves the students by assigning tasks, the student determines where, when and how and which tasks will first be performed, the teacher gives feedback1. The main focus in the style of teaching practice is to educate students to make timely decisions and also to realize the importance of time in working for oneself and for others2. In addition to repetition of movement, no less important is the provision of appropriate feedback on the appearance has been done by students. According to Dadang Suhardan, argued that effective teaching is an action of teachers who practice in carrying out their work, namely the skill in presenting the lesson material by mixing the various uses of teaching methods to present learning materials. Skills add that in addition to the training needed to develop skills, skills also require basic abilities to do the job easily and appropriately. 3 In this stage of the student's impact after warming up, then listening, noting explanations and demonstrations are given By the teacher, then the students immediately follow it sequentially part by part of the passing down movement in accordance with the repeatedly exhibited by the teacher.

In the post-meeting stage, the teacher's job gives feedback to the students about what they have done in groups, namely the lack and progress of the students in learning the bottom passing material using the practice teaching style. Feedback (feedback) is the teacher observing students individually and assess how students do activities and what should be done by teachers to improve students' skills. 4

Based on the above description, the style of teaching exercise is a systematic teaching guidebook organized by the teacher, in order to improve the success of the ability of volleyball playing skills is the 
technique of passing down and can be done repeatedly. The sequence of movements modeled by the teacher first then the students do it in groups.

The teaching style of inclusion, in this method students are encouraged to determine the level of appearance. According to Aboti5 inclusion is defined:

1. Recognition of all children and youth can learn and that all children and adolescents need support, 2. Acceptance and appreciation that all students have different ways and different learning needs as a balance value that is part of a normal human life, 3. Educational structures, systems and learning methodologies that make it possible for students. The style of inclusion provides different tasks and in this style the student is encouraged to determine the level of appearance. According to Agus Kristiyanto, Hanik Liskustyawati \& Budhi Satyawan 6

Characteristics of teaching style of inclusion (coverage), namely:

(1) The tasks assigned to the students vary, because in essence each individual has different abilities in performing the task. This style provides an individual opportunity to start from his or her own level of ability. (2) Teachers are required to design tasks in varying degrees of difficulty tailored to individual differences. The task design should also allow students to move from an easy task to a difficult task. In the Findings Beth Sanches et al 7 shows that inclusion styles can affect the degree of student involvement in physical activity lessons. Then in the results of research Jayne Jankins 8 suggests that:

(A) Selecting different levels of task difficulty when given the opportunity, and (b) Making task decisions based on perceived success and challenges. Thus, this style of inclusion teaching is an important factor in determining the success of student learning process. Therefore, if a teacher has a good teaching style, it is expected that student learning outcomes also become better.

The development of motor ability is determined by two factors: growth factor and developmental factor1. Skill is a description of one's motor skills demonstrated through the mastery of a movement2. This is in line with Widiastuti's opinion that motor ability is one of the most important indicators in fitness that is closely related to the achievement of physical quality and the quality of skills or ability of motion. Similarly gallahue and Ozmun motor skills are learning-oriented goals that make easy movement towards Difficult movements from part movement to whole body4. Motor skills in each person is different because many factors that influence it, among others, interest or willingness, age, and experience. Motor skills according to Magil is an individual skill in learning certain skills, widely determined by the level of perceptual skills and motor skills6. Ability identical to the skills in a person's performance through the potential possessed by that person. Singer states that, motor ability is the ability of a person to demonstrate his skills in doing a broad movement.

The way we use it has been developed by Gentile (USA). This model assumes that each of us learns motor skills in the same way and takes into account the conditions of its implementation, as well as 
processes related to the planning of motor skills. It is also assumed that we have memories of motor responses that we learn and then use, if the situation requires us to move.

Thus it can be concluded that if students have knowledge of their own mistakes there will be no learning of extrinsic feedback, then will accelerate learning and stabilization as well as Information about mistakes, both extrinsic and intrinsic, is important for the occurrence of learning.

\section{METHOD}

The method used in this research is experimental method with 2 × 3 factorial design. The design determination refers to Sudjana's opinion, that experimental units are grouped in cells in such a way that the experimental units inside the cell are relatively homogeneous and many experimental units inside the cell Equal to the many treatments under study8. The treatment was randomly assigned to the experimental units within each cell. The 2 x 3 factorial design design matrix is: Table 3.1 Factorial Design 2 × 3

Tabel 3.1.Desain Faktorial $2 \times 3$

\begin{tabular}{|c|c|c|c|}
\hline $\begin{array}{l}\text { Teaching Style (A) } \\
\text { Motoric competen }\end{array}$ & $\begin{array}{l}\text { Resipro } \\
\text { cal } \\
\qquad\left(\mathrm{A}_{1}\right)\end{array}$ & $\begin{array}{l}\text { Traini } \\
\text { ng } \\
\quad\left(\mathrm{A}_{2}\right)\end{array}$ & $\begin{array}{r}\text { Inclusi } \\
\left(\mathrm{A}_{3}\right)\end{array}$ \\
\hline High $\left(B_{1}\right)$ & $\mathrm{A}_{1} \mathrm{~B}_{1}$ & $\mathrm{~A}_{2} \mathrm{~B}_{1}$ & $A_{3} B_{1}$ \\
\hline Low $\left(B_{2}\right)$ & $\mathrm{A}_{1} \mathrm{~B}_{2}$ & $\mathrm{~A}_{2} \mathrm{~B}_{2}$ & $A_{3} B_{2}$ \\
\hline
\end{tabular}

The sampling technique in this research is using rasndom sampling. the total population of 236 people were taken 222 people randomly as samples in the study. The samples were then tested for motor skills in order to determine the level of motor skills of each sample. The test results are then ranked 1 222. Of the 122 students measured the level of motor skills based on Verducci's opinion

\section{RESULT}

This research was conducted in junior high school (SMP) N 3 One Roof Jl. Simonis Simpang Bandar Selamat Kabupaten Labuhan Batu Utara, North Sumatera Province in 2017. The implementation of the research, which began in March 2017, is used for the preparation, determination of research samples and preliminary tests to collect data on motor skills of the samples used. Furthermore, preliminary data are used to determine the group of high motor skills and low motor skills. To test the validation and reliability of the lower passing learning instrument, conducted by analyzing the data collected through the instrument test results. The validity of the grain of the learning instrument passing down is the validity of the content surface (facevalidity). Reliability of research instruments using retest (test-retest). The test results of the instruments analyzed by using Pearson product moment correlation. 
The next step after the test instrument, the instrument revised from the expert, then followed by a test of motor skills. The goal is to determine the level of high and low skills of students to facilitate the determination of the researcher's sample. Once determined the high and low skills of the student, will be able to proceed to the next stage of test passing under the bolavoli.

The next step To analyze the data in this study used two-way Analysis of Variance (ANAVA) with $2 \times 3$ factorial design at the significant level $\alpha=0.05$. Before performing the analysis of the variant, as a condition of meeting the requirements of data analysis, firstly tested the normality of the sample with Liliefors, the results are presented in the following table:

\begin{tabular}{|c|c|c|c|c|c|c|}
\hline \multirow{2}{*}{$\begin{array}{r}\text { Treat } \\
\text { ment Group }\end{array}$} & \multicolumn{3}{|c|}{ Kolmogorov-Smirnov $^{\mathrm{a}}$} & \multicolumn{3}{|c|}{ Shapiro-Wilk } \\
\hline & $\begin{array}{l}\text { Stat } \\
\text { istic }\end{array}$ & $\mathrm{f}$ & $\begin{array}{l}\mathrm{Si} \\
\text { g. }\end{array}$ & $\begin{array}{l}\text { Stat } \\
\text { istic }\end{array}$ & $\mathrm{f}$ & ig. \\
\hline A1 & $\begin{array}{r}0,1 \\
28\end{array}$ & 0 & $\begin{array}{r}0, \\
095\end{array}$ & $\begin{array}{r}0,9 \\
43\end{array}$ & 0 & $\begin{array}{r}0 \\
, 044\end{array}$ \\
\hline A2 & $\begin{array}{r}0,1 \\
18\end{array}$ & 0 & $\begin{array}{r}0, \\
174\end{array}$ & $\begin{array}{l}0,9 \\
66\end{array}$ & 0 & $\begin{array}{r}0 \\
, 265\end{array}$ \\
\hline A3 & $\begin{array}{l}0,1 \\
00^{2}\end{array}$ & 0 & $\begin{array}{r}0, \\
200^{*}\end{array}$ & $\begin{array}{l}0,9 \\
55^{0,9}\end{array}$ & 0 & $\begin{array}{r}0 \\
, 112\end{array}$ \\
\hline B1 & $\begin{array}{l}0,0 \\
70\end{array}$ & 0 & $\begin{array}{r}0, \\
200^{*}\end{array}$ & $\begin{array}{r}0,9 \\
81\end{array}$ & 0 & $\begin{array}{r}0 \\
, 450\end{array}$ \\
\hline B2 & $\begin{array}{r}0,0 \\
84^{0}\end{array}$ & 0 & $\begin{array}{r}0, \\
200^{*}\end{array}$ & $\begin{array}{r}0,9 \\
81\end{array}$ & 0 & $\begin{array}{r}0 \\
, 471\end{array}$ \\
\hline $\begin{array}{l}\text { A1B } \\
1\end{array}$ & $\begin{array}{r}0,1 \\
46\end{array}$ & 0 & $\begin{array}{r}0, \\
200^{*}\end{array}$ & $\begin{array}{l}0,8 \\
96\end{array}$ & 0 & $\begin{array}{r}0 \\
, 035\end{array}$ \\
\hline $2^{\text {A1B }}$ & $\begin{array}{l}0,1 \\
39^{0}\end{array}$ & 0 & $\begin{array}{r}0, \\
200^{*}\end{array}$ & $\begin{array}{l}0,9 \\
55\end{array}$ & 0 & $\begin{array}{r}0 \\
, 454\end{array}$ \\
\hline $\begin{array}{l}\text { A2B } \\
1\end{array}$ & $\begin{aligned} 0,1 \\
50\end{aligned}$ & 0 & $\begin{array}{r}0, \\
200^{*}\end{array}$ & $\begin{array}{r}0,9 \\
47^{0}\end{array}$ & 0 & $\begin{array}{r}0 \\
, 328\end{array}$ \\
\hline $2^{\mathrm{A} 2 \mathrm{~B}}$ & $\begin{array}{r}0,1 \\
45^{-1}\end{array}$ & 0 & $\begin{array}{r}0, \\
200^{*}\end{array}$ & $\begin{array}{l}0,9 \\
36\end{array}$ & 0 & $\begin{array}{r}0 \\
, 205\end{array}$ \\
\hline $\begin{array}{l}\text { A3B } \\
1\end{array}$ & $\begin{array}{l}0,1 \\
23^{0,1}\end{array}$ & 0 & $\begin{array}{r}0, \\
200^{*}\end{array}$ & $\begin{array}{r}0,9 \\
40\end{array}$ & 0 & $\begin{array}{r}0 \\
, 235\end{array}$ \\
\hline $2^{A 3 B}$ & $\begin{array}{l}0,1 \\
69^{0,1}\end{array}$ & 0 & $\begin{array}{r}0, \\
137\end{array}$ & $\begin{array}{r}0,9 \\
57\end{array}$ & 0 & $\begin{array}{r}0 \\
, 477\end{array}$ \\
\hline
\end{tabular}


The p-value (sig) result of the analysis with SPSS in each treatment group as a whole obtained a sig value of 0.05 as seen from the column sig value of Kolmogorov-Smirnova. Thus, H0 is accepted and H1 is rejected. That is, all data obtained in the treatment group has a normal distribution. Therefore, the data can be continued for the next testing process is to test the hypothesis.

Meanwhile, to find the homogeneity of population variance by using Barlett-assisted SPSS test

\begin{tabular}{|c|c|c|c|}
\hline $\begin{array}{c}\text { Levene } \\
\text { Statistic }\end{array}$ & df1 & df2 & Sig. \\
\hline 1,785 & 5 & 114 & $\mathbf{0 , 1 2 1}$ \\
\hline
\end{tabular}

Value of p-vaue $(\mathrm{sig})=0,121$ or $0,1210,05$. Then $\mathrm{H} 0$ is accepted and $\mathrm{H} 1$ is rejected. Thus, the data obtained from the learning passing results derived from the same group or population.

Furthermore, if there is an interaction (result of anova calculation) followed by Tukey test which aims to know the level of significance of $F$ arithmetic with significance level $\alpha=0,05$, or to know influence of each independent variable to dependent variable and its interaction effect.

ANAVA test results using SPSS it can be found that:

A. It means that overall there is a difference in bottom passing learning outcomes between reciprocal teaching styles, practice teaching styles, and inclusive teaching styles.

B. This means that there is a difference between high-skilled student groups and low-skilled student groups on lower passing learning outcomes.

C. Means there is a significant interaction effect between factor A (teaching style) and factor B (motor skills) on the bottom passing learning result.

Thus, the influence of teaching style, motor skills, and interaction between teaching style and motor skills to the bottom passing learning result is $70,50 \%$. The influence of the interaction between teaching style and motor skills toward lower passing learning results is presented in Figure 4.12 below. Based on ANOVA test result known that the influence of interaction between teaching style and motor skills is significant. Thus, it can be continued to test the average difference in each treatment group. This is shown in ANAVA analysis result in Table 4:229 Tests of Between-Subjects Effects of corrected model row obtained value $\mathrm{F}=54,537$ and $\mathrm{p}$-value $(\mathrm{sig})=0,0000,05$ indicating that there is significant difference of mean between each group treatment. Result of analysis of simple effect test (simple effect).

\begin{tabular}{|l|c|r|r|c|}
\hline Source & $\begin{array}{c}\text { Type III Sum } \\
\text { of Squares }\end{array}$ & Df & Mean Square & F \\
\hline Corrected & $3179,942^{\mathrm{a}}$ & 5 & 635,988 & 54,537 \\
\hline
\end{tabular}




\begin{tabular}{|l|c|c|c|c|}
\hline Model & & & & \\
\hline Intercept & $3117,342^{\mathrm{a}}$ & 5 & 623,468 & 10787,983 \\
\hline $\mathrm{A}$ & 123328,408 & 1 & 123328,408 & $\mathbf{7 6 , 0 8 5}$ \\
\hline $\mathrm{B}$ & 1739,617 & 2 & 869,808 & $\mathbf{9 8 , 1 8 1}$ \\
\hline $\mathrm{A} * \mathrm{~B}$ & 1122,408 & 1 & 1122,408 & $\mathbf{1 1 , 1 6 7}$ \\
\hline Error & 255,317 & 2 & 127,658 & \\
\hline Total & 1303,250 & 114 & & \\
\hline Corrected Total & 127749,000 & 120 & & \\
\hline
\end{tabular}




\begin{tabular}{|c|c|c|c|c|c|c|c|}
\hline & & Contrast & $\begin{array}{c}\text { Value } \\
\text { of } \\
\text { Contrast }\end{array}$ & $\begin{array}{l}\text { Std. } \\
\text { Error }\end{array}$ & $\mathrm{t}$ & $\mathrm{df}$ & $\begin{array}{c}\text { Sig. } \\
\text { (2-tailed) }\end{array}$ \\
\hline \multirow[t]{18}{*}{ output } & \multirow{9}{*}{$\begin{array}{r}\text { Ass } \\
\text { ume equal } \\
\text { variances }\end{array}$} & 1 & 3,75 & 1,069 & 3,507 & 114 & 0,001 \\
\hline & & 2 & 10,30 & 1,069 & 9,633 & 114 & 0,000 \\
\hline & & 3 & 6,55 & 1,069 & 6,126 & 114 & 0,000 \\
\hline & & 4 & $-3,35$ & 1,069 & $-3,133$ & 114 & 0,002 \\
\hline & & 5 & 6,05 & 1,069 & 5,658 & 114 & 0,000 \\
\hline & & 6 & 9,40 & 1,069 & 8,792 & 114 & 0,000 \\
\hline & & 7 & 9,90 & 1,069 & 9,259 & 114 & 0,000 \\
\hline & & 8 & 2,80 & 1,069 & 2,619 & 114 & 0,010 \\
\hline & & 9 & 5,65 & 1,069 & 5,284 & 114 & 0,000 \\
\hline & \multirow{9}{*}{$\begin{array}{c}\text { Do } \\
\text { es not } \\
\text { assume } \\
\text { equal } \\
\text { variances }\end{array}$} & 1 & 3,75 & 1,105 & 3,393 & 30,286 & 0,002 \\
\hline & & 2 & 10,30 & 1,136 & 9,069 & 32,193 & 0,000 \\
\hline & & 3 & 6,55 & 0,821 & 7,981 & 37,610 & 0,000 \\
\hline & & 4 & $-3,35$ & 1,056 & $-3,173$ & 37,517 & 0,003 \\
\hline & & 5 & 6,05 & 1,159 & 5,221 & 37,782 & 0,000 \\
\hline & & 6 & 9,40 & 1,103 & 8,522 & 36,706 & 0,000 \\
\hline & & 7 & 9,90 & 1,241 & 7,979 & 36,624 & 0,000 \\
\hline & & 8 & 2,80 & 0,893 & 3,137 & 35,922 & 0,003 \\
\hline & & 9 & 5,65 & 1,046 & 5,403 & 34,443 & 0,000 \\
\hline
\end{tabular}

The fifth hypothesis that states the learning outcomes of passing under the group of students with high motor skills and is taught by using reciprocal teaching style (A1B1) is better than the students taught with the practice teaching style (A2B1). The sixth hypothesis that states the learning outcomes of passing under groups of high-skilled motorized students and taught by using reciprocal teaching style (A1B1) is better than those taught with inclusion teaching styles (A3B1). The seventh hypothesis that states the learning outcomes of passing under the group of students with high motor skills and is taught by using the teaching-learning style (A2B1) is better than the students taught with inclusion teaching style (A3B1).

The eighth hypothesis which states the learning outcomes of passing under the low-skilled student group of students and taught by using the reciprocal teaching style (A1B2) is lower than the students taught with the practice teaching style (A2B2). The ninth hypothesis that states the learning outcomes of 
passing under the low-skilled student group of students and taught by using reciprocal teaching style (A1B2) is better than the students taught with inclusion teaching style (A3B2). The tenth hypothesis that states the learning outcomes of passing under the low-skilled student group of students and taught by using the teaching-learning style (A2B2) is better than the students taught with inclusion teaching style (A3B2).

\section{CONCLUSION}

Based on the results of research and discussion that have been put forward there are several things that can be concluded that is as follows:

1. There is a difference between the reciprocal teaching style and the exercise of overall passing down learning outcomes. 2. There is a difference between the reciprocal teaching style and the inclusion of the overall passing learning outcomes. 3. There is a difference between teaching practice style and inclusion to overall bottom passing learning outcomes. 4 . There is an interaction between teaching styles (reciprocal, exercise, and inclusion) and motor skills (high and low) to overall bottom passing learning outcomes. 5. There are differences in reciprocal teaching styles and exercises on lower passing learning outcomes in high-skilled motor students. 6. There are differences in reciprocal teaching style and inclusion to lower passing learning outcomes in high-skilled motor students. There are different styles of practice teaching and inclusion to lower passing learning outcomes in high-skilled motor students. 7. There are differences in reciprocal teaching styles and exercises on lower passing learning outcomes in low-skilled motor students. 8. There is a difference in reciprocal teaching style and inclusion to lower passing learning outcomes in low-skilled motor students. There is a difference in teaching practice style and inclusion to lower passing learning outcomes in low-skilled motor students.

\section{REFERENCES}

Abu Ahmadi, General Psychology, Jakarta: Rineka Cipta, 2009.

Ahmad, Nuril .. Bolavoli Sports Guide. Solo: Era Pustaka Utama 2007.

Amung Ma'mun Dan Toto Subroto, Tactical Skills Approach In Learning Bolavoli. Depdiknas. 2011.

Blume, Thunder. Volleyball Games (Training, Engineering, Tactics). DIP: Universitas Negeri Padang 2007.

Bompa, Tudor O. Periodization Theory and Methodology of Training. USA: Human Kinetics 2009.

Erianti .. Volleyball textbook. Padang: FIK UNP 2008.

Google.http: //rinawssuriyani.blogspot.com/2013/04/pengertian-metode-and methodology.html (accessed February 11, 2017

Gunarsa, Singgih D. PsychologySport. Jakarta: Gunung Mulia 2008.

Husdarta. Sports Psychology. Bandung: Alfabeta 2010. 
Kadir. Statistics For Social Science Research is equipped with SPSS Program Output. Jakarta: Rosemata Sampurna 2010.

Kleinmann Theo and Dieter Khuber. Volleyball coaching techniques, tactics, conditions. Jakarta: PT Gramedia 2007.

Lubis, Johansyah. Practical Guide for Preparing the Jakarta Training Program: PT. RajaGrafindo Persada 2013.

Nurhasan.Tes and Measurement In Physical Education: Principles and Its Application. Jakarta: DEPDIKBUD 2007.

N. Nurkomariah, The Influence Of Teaching Style And Motivation Of Learning To The Outcomes Of Learning Passing On Bolavoli. Pps unj: 2010

UNJ PPs Program. Thesis Writing and Dissertation Handbook.Jakarta: PPJ UNJ 2012.

PBVSI Central Board. Regulation Bolavoli.Jakarta: PBVSI 2005.

Syafruddin, Volley Ball. Padang: Universitas Negeri Padang 2008.

Syafruddin, The basics of sports coaching. Padang: DIP prpyek State University of Padang 2008.

Syahrastani. Sports Psychology. Padang: Wineka Media 2010.

Sugiyono. Educational Research Methods A Qualitative, Approach and R \& D Approach. Bandung: Alfabeta 2010.

Sukadiyanto. Introduction to Theory And Methodology Physical Train Yogyakarta: FIK UNY 2011.

Sukirno. Sports Psychology and Coaching. Palembang: Dramata 2012.

Tangkudung, James. Sports Coaching "Sports Performance Coaching". Jakarta, Smart Jaya 2012.

Widiastuti. Tests And Measurements Of Sports. Jakarta: PT. Bumi Timur Jaya. 2011

The Law of the Republic of Indonesia No.3 (2005). National Sports System. Bandung: Citra Umbara.

Uno, Hamzah B. Motivation and Measurement Theory.Jakarta: Bumi Aksara 2008.

Winardi, Motivation Motivation In Management. Jakarta: rajawali press, 2011.

Azhar arsyad. Instructional Media. Jakarta: Rajawali. 2011

Djamarah, Syaiful Bahri and Aswan Zain. Learning Teaching Strategy.Jakarta: Rineka Cipta. 2006

Slameto. Teaching and learning process. Jakarta: Teens Rosdakarya. 2008

Suyitno, Imam. Understanding the Actions of Learning. Bandung: Refoka Aditama. 2011

Shabri, H. A. Learning micro teaching strategy. Jakarta: Quantum Teaching. 2005.

Sujiono, Yuliani Nurani. Playing Creative-Based Multiple Intelligence. Jakarta: PT Index. 2010

Trianto. Designing a Progressive Innovative Learning Model: the concept, foundation, and implementation of the SBC. Jakarta: Kencana. 2009

Abdul majid, learning planning develops competency study

teacher. Bandung: PT. Rosda works, 2005 
Syaiful Bahri Djamarah \& A.Zain, Teaching and Learning Strategies. Jakarta: Rineka

Cipta, 2006

Hasbullah. Fundamentals of Science Education. PT. Raja Grafindo Persada:

Jakarta. 2005

Agus Kristiyanto, Hanik Liskustyawati \& Budhi Satyawan. Module PLPG Model, Media and Evaluation Teacher Learning Penjasorkes. Surakarta: UNS. 2011

Aunurrahman. Learning and Learning. Bandung: Alfabeta. 2009

Sanjaya, Vienna. Learning In Competence-Based Implementation-Based Curriculum. Jakarta: Kencana. 2008

Trianto, Integrated Learning Model in Theory and Practice, Jakarta: Literacy Achievement. 2007

Huda, Miftahul. Models of Teaching and Learning Methodistic and Paradigmatic Issues. Yogyakarta: Student Literature. 2013

Shoimin, Aris. Innovative Learning Model in Kurikuum 2013. Yogyakarta: Ar- Ruzz Media. 2014.

Trianto, Constructivist-Driven Innovative Learning Models, Jakarta: Achievement Library, 2007

Juang susanto, inclusion index in classroom learning which is abk disekolahdasar, journals assessment and intervention children with special needs, vol 8. No 2, 2009

Hadadian, azhar \& chiang, linda, special education training and pre-service teacher, international journal of special education, vol.22. Number 1, 200

Abosi, okey \& TL, Attaining development goal of children with disabilities: implicationj for inclusive education, international journal of special education, vol23. Number 3. 2008

Tangkudung, james. Various kinds of research methods. Jakarta: lens media media Indonesia. 2016

Gallahue \& Ozmun, Understanding Motor Development Infants, Children, Asolecents, Adults, New York: McGraw Hill, 2008

Vienna Sanjaya, Learning Strategy, (Jakarta: Preview, 2006)

Ahmad Susanto, Learning and Learning Theory, (Jakarta: Prenadamedia, 2015).

Nathaniel L gage, aconseption of teaching, springer science (standford university school of education standford, C

Google Terjemahan untuk Bisnis:Perangkat PenerjemahPenerjemah Situs Web 